\title{
DESREGULAMENTANDO DICOTOMIAS: TRANSLETRAMENTOS, SOBREVIVÊNCIAS, NASCIMENTOS
}

\section{DEREGULATING DICHOTOMIES: TRANSLITERACIES, SURVIVALS, BIRTHS}

\author{
Adriana C. Lopes* \\ Daniel N. Silva** \\ Adriana Facina*** \\ Raphael Calazans \\ Janaína Tavares ${ }^{* * * * *}$
}

\section{RESUMO}

Este artigo propõe a noção etnográfica e situada de transletramentos. Argumentamos que transletramentos são práticas de uso social da escrita que replicam e deslocam experiências de socialização mediadas por essa tecnologia e adquiridas em diversas agências de letramento portos de passagem como a escola, a igreja, a família, o grupo musical, os coletivos políticos. Baseados em evidência empírica de nossa pesquisa sobre letramentos, produção cultural e regimes metapragmáticos no Complexo do Alemão/RJ e no diálogo com Raphael Calazans e Janaína Tavares, jovens que transitam por diferentes espaço-tempos sociais, propomos ainda que transletramentos são metáforas importantes para entender a questão da sobrevivência. Ao extrapolar circunscrições como vida e morte, escola e sociedade, estado democrático e estado penal, a sobrevivência nos permite trazer à tona reflexões sobre as estratégias que os sujeitos subalternizados encontram para escrever as suas próprias histórias.

Palavras-chave: transletramentos; letramentos de sobrevivência; etnografia linguística.

\section{ABSTRACT}

This article proposes the ethnographic metaphor of transliteracies. We understand transliteracies as practices of social use of writing which replicate and displace experiences

\footnotetext{
* Universidade Federal Rural do Rio de Janeiro (UFRRJ), Rio de Janeiro (RJ), Brasil. adrianaclopes14@ gmail.com

** Universidade Federal de Santa Catarina (UFSC), Florianópolis (SC), Brasil.dnsfortal@gmail.com

*** Museu Nacional - Universidade Federal do Rio de Janeiro (UFRJ), Rio de Janeiro (RJ), Brasil. adriana.facina2@gmail.com

**** Universidade Federal do Rio de Janeiro (UFRJ), Rio de Janeiro (RJ), Brasil. calazaaaans@gmail. com

***** Universidade Federal Rural do Rio de Janeiro (UFRRJ), Rio de Janeiro (RJ), Brasil. janaa. tavaresv@gmail.com
} 
of socialization mediated by the technology of writing and acquired in multiple literacy agencies - transit points such as the school, the church, the family, the musical group, the political group. Based on empirical evidence from our research on literacies, cultural production and metapragmatic regimes in the Complexo do Alemão/RJ and on the dialogue with Raphael Calazans and Janaína Tavares, youths who circulate around different social time-spaces, we also argue that transliteracies are important metaphors to understanding the question of survival. While exceeding modern boundaries such as life and death, school and society, rule of law and penal state, survival permits that we think about the strategies devised by subaltern subjects in their inscribing of their own histories.

Keywords: transliteracies; literacies of survival; linguistic ethnography.

\section{INTRODUÇÃO}

Este artigo busca responder a algumas indagações que acompanham, por vezes angustiam, pessoas interessadas na educação de jovens das periferias do Brasil ${ }^{1}$. Essas indagações têm a ver com a aquisição, a performance e a transformação de uma "tecnologia fundante da sociabilidade humana para a maioria dos habitantes do planeta hoje, ainda em que em diferentes graus" (GARCEZ, 2017, p.6), a saber, a escrita. De diferentes maneiras, conversas em coletivos de minorias de gênero, raciais, sexuais etc., em cursos de formação de professores, em debates linguísticos ou antropológicos sobre a juventude de periferias (e em outros lugares) lançam indagações sobre o papel de agências de letramento como a escola no acesso a essa tecnologia, sobre os tipos de "muros" que os mecanismos do Estado de Direito erigem para evitar que essas/esses jovens periféricos adentrem espaços de poder na sociedade, sobre os tipos de "reexistência" (SOUZA, 2011) que essas/esses jovens conseguem inscrever ao tentar pular esses muros.

Aqui, marcaremos uma posição diante dessas indagações propondo a noção de 'transletramentos'. Ao dialogar com dois jovens de periferia, Raphael Calazans e Janaína Tavares - aqui considerados coautores em vez de informantes desta reflexão -, propomos que transletramentos são práticas de uso social da escrita que replicam

1. O que você lerá a seguir é também um posicionamento multiautoral e multitemporal à demanda proposta por Inês Signorini e Raquel Salek Fiad ao conjunto de professoras e professores que participaram das primeiras duas edições do Seminário sobre Letramento e Transdisciplinaridade (realizadas no IEL/Unicamp, respectivamente, nos dias 08 e 09 de maio e 29 e 30 de agosto de 2017). Esses seminários têm se proposto a produzir novos posicionamentos diante da questão dos letramentos na sociedade. Participaram do primeiro seminário: Daniel Silva, Emilio Pagotto, Luiz André Neves de Britto, Neusa Salim Miranda e Pedro Garcez, além das organizadoras, Inês Signorini e Raquel Fiad. Participaram do segundo: Camila Scheifer, Daniel Silva, Emilio Pagotto, Ines Signorini, Pedro Garcez e Raquel Fiad. Agradecemos às/os participantes do segundo seminário pela leitura crítica e sugestões a este artigo. Somos gratas/os também a Viviane Veras e Branca Fabrício pela leitura e comentários. As falhas que tiverem permanecido são de nossa responsabilidade. 
e deslocam experiências de socialização mediadas por essa tecnologia e adquiridas em diversas agências de letramento (STREET, 2014; KLEIMAN, 1995) - portos de passagem como a escola, a igreja, a família, o grupo musical, os coletivos etc. Como demonstraremos a seguir, transletramentos são uma metáfora que emerge de nossa compreensão etnográfica da circulação da escrita na sociedade. Trata-se de uma forma de imaginar as trajetórias pela escrita que os sujeitos percorrem em sua mobilidade por diferentes espaços-tempos da cidade. Assim, nossa forma de entender essa metáfora difere do conceito de transletramentos proposto por Thomas et al (2007) - i.e., "a habilidade de ler, escrever e interagir através de um espectro de plataformas, ferramentas e meios, desde a gestualidade [signing] e a oralidade, passando pela escrita à mão, a $\mathrm{TV}$, o rádio e o filme, até as redes sociais digitais." Ao passo que não discordamos dessa definição, uma vez que a sociabilidade pela escrita no mundo contemporâneo de fato se dá através de diferentes plataformas e meios, preferimos entender transletramentos como ícones da mobilidade e da socialização dos sujeitos à medida em que se inscrevem em eventos de letramento - ao mesmo tempo que transbordam tais eventos ao invocarem trajetórias prévias e futuras de socialização na escrita. Escrever, nesse sentido, é traduzir - transformar enunciados prévios (e imaginar futuros).

Transletramentos são também metáforas para entender os letramentos de sobrevivência (LOPES, SILVA \& FACINA, 2014, MAIA, 2017), práticas escriturais de sujeitos subalternizados que desafiam o letramento formal e pedagogizado (uma vez que estão a um só tempo "dentro" e "fora" dele) e, por conseguinte, o grafocentrismo, a dicotomia oral/escrito, bem como os princípios de racionalidade e de individualismo que permeiam as definições eurocêntricas daquilo que conta como "escrita" na modernidade. Os letramentos de sobrevivência são rastros que resistem - rastros indiciadores de que aqueles que foram subalternizados pela modernidade não se entregam pacificamente à escrita, mas dela se apropriam, transformando seus significados e reinventando formas de sobreviver culturalmente.

O texto está organizado do seguinte modo. Na seção 1, argumentamos que as circunscrições hegemônicas do que se tem chamado de "a língua" e "a escrita" coincidem com imagens específicas de tempo, espaço e pessoa (i.e., os cronotopos de Bakhtin); embora específicas, essas imagens são dominantes e geram um grande número de dicotomias, como letramento hegemônico/letramento vernacular, fora/dentro da escola, fora/dentro do padrão culto da língua. Ao longo do artigo, argumentamos que alguns polos das oposições acima podem funcionar como "muros", impedindo acesso a recursos linguísticos e semióticos. Na seção 2, apresentamos algumas nuances da polivocalidade deste artigo, explicitando o modo como os/ 
as diversos autores/as têm dialogado e a forma como Adriana Lopes demandou as narrativas de Calazans e Janaína. As seções 3 e 4, respectivamente 'Sobrevivências' e 'Nascimentos', são o ponto central deste artigo: narrativas em que esses dois jovens se posicionam sobre suas trajetórias de letramentos. A seção 5 "teoriza" sobre nascimentos e sobrevivências. Dito de outro modo, nela argumentamos que o diálogo com a perspectiva de sujeitos que não ocupam o centro das circunscrições hegemônicas pode revelar que a aparente "exclusão" é também fluida e porosa; dito de outro modo, se vista de forma não-dicotômica, a socialização em letramentos e usos da linguagem é muito menos uma questão de "dentro/fora" da escola ou da comunidade do que de "trajetórias de socialização" (BORBA, 2016); sujeitos ditos marginalizados transitam por vários espaços da cidade e, nesse trajeto, passam a incorporar formas de escrever, ler e habitar práticas de um modo que é irredutível a espaços circunscritos, como "a" escola, "a" língua (culta), "a" favela, "a" igreja. Ainda nesta seção, argumentamos que, em vista da impossibilidade de confinar tanto as trajetórias de socialização na escrita dos sujeitos quanto suas formas éticas de habitar práticas a uma circunscrição específica, letramentos podem ser imaginados como transletramentos, isto é, como formas de uso de recursos gráficos das sociedades globalizadas que reiteram experiências de socialização na leitura e na escrita, não se reduzindo nem a um regime (KROSKRITY, 2000) nem a uma agência de letramento (KLEIMAN, 1995) específicos. A seção 6 e as considerações finais dão atenção a práticas transletradas de sobrevivência, em função de nosso engajamento com sujeitos que, de múltiplas formas, transitam por contextos que transbordam divisões como vida e morte, escola e sociedade, estado democrático e estado penal.

\section{CIRCUNSCRIÇÕES}

Espaço e tempo, duas categorias tomadas pela filosofia de Kant como condições a priori de qualquer forma de conhecimento, estão presentes no pensamento linguístico moderno desde Saussure, com sua imaginação do espaço ocupado pelos falantes da langue e com sua dicotomia sincronia $\mathrm{x}$ diacronia, cujos elementos relacionam-se, respectivamente, ao tempo das/os falantes e da história das línguas. Nossa posição aqui é a de que a episteme modernista - ou, mais precisamente, ideologia linguística (SILVERSTEIN, 1979, p.193), i.e., "quaisquer conjuntos de crenças sobre a linguagem articuladas pelos usuários como racionalização ou justificação de estrutura e uso linguístico percebidos" - forjada por Saussure em suas aulas de linguística geral e reciclada em diferentes tradições do pensamento 
moderno sobre a linguagem circunscreveu o objeto "língua" (a langue saussuriana), decalcando-o da radical heterogeneidade das práticas linguísticas do dia-a-dia (a parole saussuriana), e o fizeram, numa operação subsequente, coincidir com imagens particulares de espaço e tempo-e-pessoa, os cronotopos de que fala Bakhtin em seu estudo das configurações de tempo e espaço do romance. (Diz Bakhtin (1981, p.580) que cronotopos são "uma condensação e concretização espaciais dos índices do tempo - tempo da vida humana, tempo histórico - em regiões definidas do espaço." Ele acrescenta que, na literatura, a imagem da pessoa humana é "sempre intrinsecamente cronotópica", p.85).

Nos estudos da linguagem, a operação de decalque e transferência a que aludimos acima - isto é, a "purificação" (LATOUR, 1994) da língua e a "iconização" (IRVINE \& GAL, 2000) do artefato purificado, doravante mapeado como característica intrínseca de seus falantes - gerou uma imagem de falantes circunscritas/ os, seres "fixos, por assim dizer, no espaço e no tempo" (BLOMMAERT, 2010, p.4) ${ }^{2}$. Nos termos da crítica de Joana Plaza Pinto (2013) às operações de purificação de artefatos teóricos na sociolinguística brasileira, a operação de iconização das/os falantes é prévia à própria análise do fato sociolinguístico - o que a autora chama de prefiguração identitária. Nesse sentido, descrições de variedades e das habilidades metalinguísticas das/os falantes desses estratos linguísticos correspondem a imagens bastante concretas de pessoa, com traços raciais, de classe, sexualidade e gênero muito específicos. Por exemplo, na distinção entre variedade culta e variedades populares em Castilho \& Pretti (1987), Pinto (2013, p.127-128) identifica a transferência de privilégios de classe à descrição da consciência metalinguística das/ os falantes ditas/os cultas/os:

os privilégios de classe são coextensivos aos privilégios linguísticos: "é óbvio" [dizem Castilho \& Pretti] que as classes cultas não são apenas "privilegiadas", "escolarizadas" e "letradas" são também as mais linguisticamente hábeis; "são os falantes cultos, por certo, os que possuem maior consciência da variação linguística e de sua adequação à grande diversidade de situações de comunicação" (Castilho \& Pretti, 1987:3). Acaba-se encontrando aqui mais uma ideia integrante do critério zero: a fetichização do dialeto de prestígio e de seus falantes. Falantes

2. Para Latour (1994), a palavra 'moderno' implica dois tipos de operações: tradução e purificação. No primeiro tipo, criam-se "misturas entre gêneros de seres completamente novos, híbridos de natureza e cultura" (p.16); no segundo tipo de operações, zonas ontológicas distintas são separadas, isto é, "purificadas": "a dos humanos de um lado, e dos não-humanos, de outro" (p.16). Nos termos de Bauman \& Briggs (2003), a criação de uma esfera moderna no pensamento sobre a linguagem significou a purificação do objeto língua - a langue saussuriana por exemplo - extraído da zona híbrida das relações contextuais e indexicais, em que signo e contexto, língua e pertencimento social se encontram misturadas. Nos termos de Latour, ser moderno significa considerar separado os dois conjuntos de práticas; a partir do momento em que olhamos para a interdependência das duas práticas, "deixamos instantaneamente de ser modernos, nosso destino começa a mudar" (p.16). 
cultos são linguisticamente melhores que os não cultos; enquanto os "populares" não sabem transitar entre variedades e dialetos, ficando "presos" à variedade que conhecem, os "cultos" adaptam-se à situação de comunicação.

Essa imagem prefigurada de falantes de dialetos populares como "presos" ao espaço-tempo de suas variedades não se sustenta empiricamente. Basta um pouco de sensibilidade para perceber que, no Brasil, as/os habitantes de periferias percorrem grandes distâncias nos centros urbanos, certamente circulando mais entre espaços sociais do que moradoras/es de bairros centrais.

Adiante, as seções 'Sobrevivências' e 'Nascimentos' - redigidas pelos coautores Raphael Calazans e Janaína Tavares, moradores de espaços altamente periferizados no Rio de Janeiro - revelam práticas sempre em fluxo de moradoras/ es de periferias: seus trânsitos entre espaços urbanos, instituições e variedades linguísticas constituem uma imensa rede, transbordando o espaço-tempo da favela e da periferia. Sujeitos móveis, eles estão a um só tempo "dentro" e "fora" da escola, "dentro" e "fora" da periferia, "dentro" e "fora" do dialeto culto. Suas relações com a fala e com a escrita indexam pertencimentos em trânsito.

É nossa posição neste artigo que as trajetórias de socialização de Calazans e Janaína ${ }^{3}$ colocam em xeque circunscrições correntes nos estudos da linguagem e dos letramentos. Por exemplo, como compreender a "escrita" sobre as "escritas" nas histórias de Calazans e Janaína? Como circunscrever os "eventos" de letramento, bem como as "agências" de letramento (STREET, 2014) narrados em "Sobrevivências" e "Nascimentos"? Como ler sua habilidade metalinguística vis-àvis a posição prefigurada de Castilho \& Pretti, icônica de outros posicionamentos nos estudos da linguagem?

Cabe destacar que compreendemos a escrita como um objeto etnográfico por natureza (STREET, 2009; BLOMMAERT, 2008). Produto de um movimento ou, nos termos de Silverstein \& Urban (1996), de uma "história natural" - a escrita indicia a complexidade de seus múltiplos contextos. Etnografia é aqui trabalhada como um princípio dialógico de pesquisa e não como um método (BLOMMAERT, 2008). Segundo Clifford (1986), as "verdades" etnográficas são sempre parciais, engajadas e incompletas. Assim, se os dados no campo são construídos de forma coletiva e interacional, este texto se apresenta então como uma montagem textual em coautoria, assumindo não só que o conhecimento é poder, mas que a escrita

3. Raphael Calazans e Janaína Tavares se autodenominam MC Calazans e MC Janaína. Ao longo do artigo, utilizaremos majoritariamente as formas Calazans e Janaína, em virtude do modo como são conhecidos nas interações no campo; ocasionalmente, a forma ' $M C$ ' e o nome completo também serão utilizados. 
também o é. Tal montagem busca responder a duas crises estabelecidas nos estudos etnográficos a partir dos anos de 1980 (BEHAR \& GORDON, 1995). A primeira delas diz respeito ao reconhecimento de que os/as antropólogos/as não só interpretam o Outro, mas sobretudo 'escrevem' sobre o Outro (CLIFFORD \& MARCUS, 1986). E a segunda crise, intrinsecamente relacionada com a primeira, tem a ver com o poder da escrita na sociedade contemporânea e parte do seguinte questionamento: no interior do "território" acadêmico, quem tem o poder de escrever sobre quem? (MORAGA \& ANZALDÚA, 1981)

Inspiradas/os por Gloria Anzaldúa (2000), compreendemos que é necessário desconstruir as ideologias que circunscrevem a imaginação sobre o que é um escritor ${ }^{4}$. Tradicionalmente, essa imaginação está fundamentada em uma noção de autoria como expressão de um indivíduo soberano. Já que esta pesquisa propõe um tipo de produção de conhecimento fundamentada pela circulação, pela troca de diversos saberes e pela reciprocidade entre pessoas envolvidas, buscamos borrar fronteiras entre sujeitos pesquisadores e pesquisados. Portanto, se no trabalho político de investigação sobre os letramentos todos/as se engajaram como pesquisadores/as e escritores/as, este artigo não apresenta "informantes-chave" ou "falantes nativos", mas sim pessoas que se constituíram como escritoras ao longo desta pesquisa. Assim, em vez de "informantes", MC Calazans e MC Janaína são coautores da presente reflexão - não apenas por terem redigido, respectivamente, as seções 4 e 5 da presente narrativa, mas também porque suas vozes se misturam e se entextualizam em todo o artigo, sobrevivendo em uma escrita que indicia a pluralidade. Dito isso,

4. A essa imagem do escritor solitário trabalhando no silêncio de seu escritório corresponde a figura do homem branco e europeu. Nos termos de Anzaldúa (2000), este escritor seria aquele que sempre teve a sua escrita financiada, capitalizando para si não só o poder da escrita, mas sobretudo o poder da narrativa e da autoria. Nessa mesma direção, Virgínia Woolf, no romance O Teto Todo Seu (2014 [1928]), pergunta o seguinte: se Shakespeare tivesse uma irmã com o mesmo talento do irmão, haveria um quarto só para ela? Ela teria uma vida inteira para escrever? No século XVI, certamente não. Parecendo ouvir os ecos da narrativa de Woolf, Anzaldúa (2000) escreve sobre as mulheres da periferia do mundo; mulheres que nunca tiveram "um quarto só para $\mathrm{si}^{\prime \prime}$, mas que, certamente, são escritoras e autoras do século XXI. Nas palavras de Anzaldúa (2000, p.233): “E quem tem tempo ou energia para escrever, depois de cuidar do marido ou amante, crianças e muitas vezes do trabalho fora de casa? Os problemas parecem insuperáveis, e são, mas deixam de ser quando decidimos que, mesmo casadas ou com filhos ou trabalhando fora, iremos achar um tempo para escrever. Esqueça o quarto só para si - escreva na cozinha, tranque-se no banheiro. Escreva no ônibus ou na fila da previdência social, no trabalho ou durante as refeições, entre o dormir e o acordar. Eu escrevo sentada no vaso. Não se demore na máquina de escrever, exceto se você for saudável ou tiver um patrocinador — você pode mesmo nem possuir uma máquina de escrever. Enquanto lava o chão, ou as roupas, escute as palavras ecoando em seu corpo. Quando estiver deprimida, brava, machucada, quando for possuída por compaixão e amor. Quando não tiver outra saída senão escrever." 
nas próximas sessões detalharemos a forma como a polivocalidade desta múltipla autoria foi orquestrada.

\section{DEMANDA POR NARRATIVAS 5}

Calazans, jovem, negro, nascido no Complexo do Alemão, MC do Funk, cursou entre 2013 e 2017 Serviço Social na Universidade Federal do Rio de Janeiro (UFRJ). Janaína, jovem, branca, nascida na Baixada Fluminense, organizadora de um dos Saraus que acontece na cidade de Nova Iguaçu, cursa Letras na Universidade Federal Rural do Rio de Janeiro (UFRRJ). Mesmo morando e estudando em lugares distintos, os dois se conhecem, pois participam (ou participaram) de partidos políticos de esquerda e de grupos militantes pelos direitos humanos, mais especificamente de coletivos que trabalham com cultura, violência e juventude. Ambos fizeram parte da Associação de Profissionais e Amigos do Funk (Apafunk), um coletivo que, entre outras coisas, procurou criar canais alternativos de comunicação com a sociedade, buscando combater estigmas ligados às produções culturais periféricas, principalmente discursos e práticas que criminalizam o Funk Carioca.

Calazans, Janaína, Adriana Lopes e Adriana Facina tiveram suas histórias cruzadas na Apafunk. Em outros espaços de ativismo e pesquisa, como o Museu Nacional da UFRJ e o Instituto Raízes em Movimento, no Complexo do Alemão, Calazans, Adriana Facina, Adriana Lopes e Daniel cruzaram caminhos. Adriana Lopes e Adriana Facina foram sócias fundadoras da Apafunk. Adriana Lopes escreveu um livro destacando que tal associação permitiu que o funk fosse significado como uma forma de mobilização social em torno da reivindicação e da promoção de direitos não só para os artistas do funk, mas para a juventude de periferias e favelas (LOPES, 2011). Os artistas da Apafunk organizaram, por um longo período, eventos culturais pela cidade do Rio de Janeiro, como Rodas de Funk ou Saraus.

Por um certo período, Calazans passou a atuar diretamente na Apafunk, como MC, produzindo o que ele chamou de primeiro funk crítico às Unidades de Polícia Pacificadora (UPPs), presentes na região onde ele mora. Janaína, por sua vez, entendeu que com os Saraus da Apafunk a poesia estava nas ruas. A partir da

5. Utilizamos a expressão "demanda por narrativas" fazendo referência a um dos escritos de Jacques Derrida, "Living on/ Border Lines" (1979). Para o filósofo, já que as narrativas não têm a propriedade de dizer tudo como aconteceu "à risca", deveríamos nos perguntar sobre "qual é a demanda para a produção de uma determinada narrativa?" A resposta a essa pergunta, apesar de não estar explicitamente no texto, é constitutiva dos sentidos que ali serão tecidos. Por exemplo, a partir de qual demanda se produz uma narrativa? Uma demanda policial, escolar, amorosa etc.? Pensar qual é a demanda é compreender os efeitos de sentido que certa narrativa encena e provoca. 
vivência nesses eventos, que aconteciam mensalmente no centro da cidade do Rio de Janeiro, Janaína decidiu criar um Sarau em Nova Iguaçu, chamado Sarau "V" de Viral. Mas o restante dessas histórias será apresentado nas próximas seções. Por ora voltaremos à demanda de produção das narrativas.

No primeiro semestre de 2015, convivemos - Raphael Calazans, Adriana Lopes, Adriana Facina e Daniel Silva - quase que semanalmente; Adriana Lopes e Janaína, em outro contexto, também conviviam semanalmente. Mas diferentemente de outros momentos, os encontros de todas/os, a partir de 2015, passaram a acontecer na Universidade. Calazans foi um dos idealizadores do curso "Sobreviver/ Sobrevivências", ministrado por Adriana Facina, Adriana Lopes e Daniel Silva no curso de Pós-Graduação em Antropologia Social do Museu Nacional da UFRJ, onde Facina atua como professora. Janaína, por sua vez, começou a trabalhar com Adriana Lopes quinzenalmente na UFRRJ, na leitura da revisão bibliográfica para a elaboração de sua monografia, que tem como tema os letramentos e as identidades do Sarau V. Esses encontros foram muito produtivos: dois sujeitos únicos, mas que, aos poucos, pareciam tecer histórias de letramentos semelhantes em tantos pontos; histórias que mostram algo que a escola quase sempre negligencia: aprender a escrever não é aprender uma técnica neutra, mas sim aprender a posicionar-se no mundo a partir de uma determinada experiência singular e dos recursos disponíveis.

Ao final do semestre, Adriana Lopes solicitou que cada um deles produzisse uma narrativa sobre a sua história de letramento para que pudéssemos fazer um artigo em conjunto para ser publicado. Ambos ficaram altamente empolgados com a ideia. São jovens que têm um gosto especial pela escrita e fazem isso cotidianamente. Parafraseando e juntando trechos das narrativas de Calazans e de Janaína: "são jovens que já escreviam, antes mesmo de aprender a escrever."

Passemos então às narrativas de Raphael Calazans e Janaína Tavares.

\section{SOBREVIVÊNCIAS}

A minha história se confunde com a de muitos outros moleques, negros, pobres, nascidos no início da década de 1990; moleques que nasceram junto com o surgimento do "símbolo favela" e a sua circulação nos jornais e no imaginário da população do asfalto. Os morros da Zona Norte e Oeste, o mundo para além do Rebouças, antes desconhecidos e reclusos, cada vez mais se aproximavam das terras nobres da Zona Sul. Muito especialmente através do nascimento do Movimento Funk. Esse, quase um irmão gêmeo, que hoje é meu melhor amigo e minha mais potente arma, também foi meu primeiro professor; os bailes, a minha primeira 
escola, meu jornal, meu livro e minha caixa de depósito de tristezas e de saudades. Venho ao mundo, na década que a favela começa a pular o muro da cidade partida, por isso, não à toa, toda minha caminhada tem sido nesse sentido: pular os muros, mas nunca esquecer o meu verdadeiro lado, até a completa derrubada desses muros.

Meu pai, José Carlos, ou como é conhecido, o "Zé Borracha", saía de Santa Cruz, Zona Oeste do Rio de Janeiro, para trabalhar como borracheiro na Penha, bairro da Zona Norte. Como a viagem era longa, vez ou outra, ficava na casa de amigos, no conjunto de favelas do Complexo do Alemão. Lugar onde fez grandes amizades, passando a ser conhecido por todos da área. Mudou-se para lá com minha mãe e minha irmã mais velha. Minha mãe passou a ser zeladora de uma igreja presbiteriana.

No fundo dessa igreja nasci e tive meus primeiros contatos com o mundo. Devo à Igreja a barriga cheia, por nunca ter passado fome, a casa pequena, de um cômodo, que foi cedida à minha família. Mas o meu principal ganho foi o contato com a música gospel. Causava-me bastante emoção ver a música negra ecoando nas vozes graves das simpáticas senhoras e de um senhorzinho franzino, negro e pobre, tocando um contrabaixo.

Ainda que a Igreja, a música Gospel e o Samba tivessem importante peso na minha trajetória, foi a vida no Complexo do Alemão em que eu, o "borrachinha", filho do "Zé Borracha", iniciei os grandes estudos da minha vida. Ruas, becos, amigos, brigas, aniversários, calote de ônibus, bailes, muitos bailes. Vivendo entre o perigo dramático da violência no dia-a-dia das operações policiais e a correria cotidiana para inventar a sobrevivência, comecei a ler o mundo que estava ao meu redor. Se por um lado, a pobreza, a ausência de serviços públicos, a falta de saneamento básico colocavam-se como prisões que não nos permitiam sair "desse lugar"; por outro lado, foi a partir dessa escassez que aprendi e comecei a me alfabetizar.

Tiê e Playboy, dois pretinhos, uma das primeiras duplas de MCs do já movimento bombástico da cidade, o Funk, foram as minhas inspirações primárias. No contexto de brigas nos bailes e de formação dos bondes no Alemão (o da Fazendinha e o da Grota), a dupla lançou uma música que virou febre na comunidade, o "Rap da Mudança". Eles cantavam assim: "Se entre duas pedras nasce uma flor/ Entre os funkeiros pode nascer o amor/Papapapapare pare pra pensar/Papapapapare pare Dj pode soltar"

Muito impactado por essa música, que falava de amor, pedra, favela, briga: coisas tão antagônicas entre si, mas que faziam todo o sentido em quem vivia por aqui. Fui percebendo que nas favelas as dicotomias não faziam muito sentido. $\mathrm{O}$ traficante "mal", "diabólico", era o colega que curtia as festas comigo. A pobreza, 
a fome e a violência não impediam que existissem relações amorosas, embora nos filmes e nas novelas, o cenário de amor sempre fosse a "praia" ou um lugar "bonito", "rico" e "harmônico". Nesse sentido, meus amigos e eu, mesmo sem sabermos escrever, escrevíamos sobre tudo que vivenciávamos e sentíamos no Complexo. Eram brincadeiras de escrever "rap's", sobre esse mundo onde os antagônicos encaixam-se e formam um quadro por meio do qual desenhamos a vida. Aqui, viver e morrer, chorar e rir, dor e alegria eram sinônimos. De modo que escrevíamos, colocávamos as letras que não combinavam e eram sem sentido, de acordo com a escrita escolarizada, mas eram os nossos sentimentos que davam sentido à caneta $\mathrm{e}$ ao papel. E, assim, após ser alfabetizado pelos becos, eu traduzi o meu primeiro rap:

"Obá, obá, obá....ôôô...amigos de verdade, / é o nosso bonde, demoro./Aqui do beco da 10, /da Nova Brasília, /vejo a Danila/os meus olhos até brilha./ Se fosse um cara rico,/ um homem de valor,/ compraria até o sol/ e dava prá você, meu amor"

Porém, a favela é onde os meninos tornam-se homem mais cedo. E isso valeu para mim quando, aos 12 anos de idade, após uma das operações mais violentas no Complexo do Alemão, perdi dois dos meus melhores amigos, além de um primo, sobrinho do meu pai, que morreu na nossa frente. Naquele momento, tive que optar por "ser alguém", deixar de ter apelido e ter um nome. Deixar de andar nos becos e andar nas ruas; deixar de falar gíria e falar de acordo com a gramática. Ou seja, tive de deixar de escrever e ler a favela pelo funk e entrar para a escola.

O chamado para isso veio pelos meus pais, já envelhecidos, doentes e preocupados comigo - a última esperança viva da família. Eles tinham medo que eu me perdesse no morro e virasse estatística. Assim, minha mãe limparia o chão da igreja, mesmo que sua coluna estivesse já bastante comprometida, para pagar um cursinho preparatório. Seu sonho era que estudasse numa escola que me desse, no mínimo, a chance de pegar um ônibus para fora dos braços do Complexo do Alemão.

Já bastante emocionado pelas perdas dos amigos e o apelo da família, abracei o projeto com determinação. Mesmo sabendo que as chances eram muito poucas: um filho da periferia carioca, filho de uma zeladora e de um pai borracheiro semianalfabetos, disputar vaga nas escolas mais tradicionais da cidade.

Porém, embalado nos CDs dos Racionais, fugindo do drama para "não ser mais um preto fudido", fui aprovado para cursar o ensino médio no Colégio Pedro II, onde conheci o grêmio e o movimento estudantis. No ano seguinte, no entanto, fui aprovado para a Escola Politécnica de Saúde Joaquim Venâncio (EPSJV) da Fundação Oswaldo Cruz. Foi lá que minha vida deu um giro. Como um dos poucos negros e pobres da escola, tive que forçar a minha "intrusão social", disputando com 
os demais alunos que estavam bem à frente de mim na escolarização. Compensei a dificuldade de leitura e escrita com muito esforço. Naquele lugar, vivi dez anos em três!

Por ser uma escola que pretende construir uma educação crítica, havia um grande incentivo à participação política dos alunos em movimentos sociais e na vida política da própria instituição. Lá eu conheci e participei de diversos movimentos sociais. Tive contato com a literatura marxista, participei de grupos de estudos. Ao circular pela cidade, encontrei pessoas e um mundo novo bem diferente e distinto do que tinha conhecido até então. Foram anos intensos de muito estudos, articulações e conhecimentos. Fui liderança do grêmio da escola, passei a ser um aluno respeitado pelo meu engajamento político.

Foi no ano de 2010, época da Campanha de reeleição do Deputado Marcelo Freixo do Partido Socialista e Liberdade (PSOL), que conheci outros movimentos populares definitivos na minha história. Grupos que organizavam suas reivindicações em torno de críticas às Unidades de Polícias Pacificadoras (UPPs) instaladas em algumas favelas da cidade do Rio de Janeiro. Nesse contexto, conheci pessoas que estudavam a criminalização da pobreza, a cultura popular e grupos político-culturais que agitavam a cidade. Sem perceber já estava voltando para a favela, agora de forma mais ampla, coletiva e crítica. Mal sabia que esses grupos e pessoas que ali encontrei - do qual destaco a Apafunk e a professora Adriana Facina, o Fórum de Juventudes do Rio de Janeiro e o reencontro com meu parceiro de vida, Alan Brum, do Instituto Raízes em Movimento - seriam tão importantes.

Aos poucos, portanto, estava "voltando para o Complexo". A própria formação acadêmica me levou a isso: o meu trabalho de conclusão de curso foi sobre o funk no Alemão - assim, a retomada do meu território foi imprescindível e inevitável. Naquele momento, o Complexo iniciou um dos processos mais violentos da sua história: a instalação da UPP. Em 27 de Novembro de 2010, as tropas militares invadiram e ocuparam o território. Foi o início de um novo contexto em que o dramático aumento das violações dos direitos foi acompanhado por múltiplas formas de resistência e sobrevivência criadas pelos atores sociais locais.

Eu já não era o mesmo, nem o Complexo também era. Da minha geração, quase metade foi morta ou presa. Lugares, amigos, bailes, minha primeira e decisiva escola estava sob escombros. Eu mesmo, enquanto estudante, militante, já não tinha mais a "pegada dos becos", talvez por ter me tornado um "pretinho tipo A", como diz Mano Brown. Isso me trouxe uma série de confusões: de tanto criticar e me esforçar para compreender criticamente a sociedade, precisava eu mesmo passar por uma autocrítica: até que ponto valeu a pena minha "intrusão social"? Qual validade 
daquilo para o meu lugar? A autocrítica permanece comigo até os dias atuais, porém decidi voltar para o Complexo, de volta para o banco de aluno. Foi quando assumi minha profissão $\mathrm{MC}$, tendo gravado a música "Polícia Passa e fica a dor", a primeira música de crítica do funk à UPP. Voltei para o Instituto Raízes em Movimento e passei a participar da vida política do território, num momento especial e delicado. Articulei coletivos, fracassei em muitos. Os bailes já não existiam e agora também não existem mais, porém ficou a luta por eles. Percebi que ao pular o muro da cidade partida, me tornei um pouco como aqueles que moravam do outro lado do mundo e, de certa forma, demorei muito a voltar. E essa volta só assume sentido para mim se for para a derrubada completa desse muro.

Ao ler a favela e me alfabetizar pela metodologia da cultura viva e criativa da sobrevivência, que reinventa a vida a partir daquilo que nega a própria vida, percebi que a "Escola do asfalto" não é mais importante ou sofisticada e detentora do verdadeiro conhecimento. Durante um tempo confundi esses papéis e foi onde mais perdi tempo. Para exemplificar isso termino com uma história, que é muito cara e significativa, por explicitar bem tudo isso. Nas minhas voltas da Fiocruz, eu sempre entrava no Alemão de jaleco e com livros na mão. Certa vez, um grande amigo, que naquela altura havia se tornado traficante, me pediu emprestado um "daqueles livros de política que eu sempre lia". Nunca levei esse pedido a sério, uma vez que ele era semianalfabeto, tendo apenas estudado comigo nas ruas. Nunca entenderia o que aquele texto argumentava, nem o que significavam as expressões neoliberalismo, capitalismo etc. Tempo depois, na invasão do exército, ele morre. Fiquei triste por não tê-lo presenteado com o livro, mas dediquei a ele a minha monografia sobre funk e favela. Era um texto meu, sobre tudo aquilo que vivemos e até certo ponto, sobrevivemos. Das nossas escritas, da nossa escola nos becos, dos nossos momentos e das dificuldades que enfrentamos. Esse é o preço de você abandonar os seus estudos e ir para escola. Preço que pago até hoje: o de refletir, por fora, tudo aquilo que você aprendeu e viveu, por dentro.

\section{NASCIMENTOS}

A primeira vez que nasci foi nos anos de 1990. Cresci ouvindo funk melody, tomando Guaraná Simba e jogando um Super Nintendo velho que tinha passado de mão em mão. A vida no subúrbio do Rio, especificamente na cidade de Nova Iguaçu, lugar que cresci e vivo até hoje, foi boa apesar dos grandes índices de violência que assombram essa região. A rua foi minha primeira escola, a minha primeira rotina. Diferente de hoje, ela vivia cheia, crianças correndo pra todo lado e os adultos no 
portão. A rua ajudou a costurar minha infância e a esquecer das brigas causadas pelo alcoolismo do meu pai e dos meus tios que davam trabalho. Eu brincava de tudo um pouco, pique-bandeira, queimada, pique-esconde e corria com medo dos bate-bolas no período de carnaval. Sempre me escondia atrás dos cabelos brancos e crespos da minha vó, que cheirava a leite de rosa e ficava sentada no portão tomando cerveja nas noites de verão. Mesmo de família humilde e a casa cheia, eu sempre gostei de estudar e tinha meus momentos introspectivos. E o que me iniciou na literatura foi a sensação da garotada daquela época: Harry Potter. Devorava a história daquele jovem bruxo europeu que era desprezado pelos tios, mas tinha um refúgio justamente na escola. Estudei até o último ano do ensino fundamental nessas escolas particulares pequenas de bairro em que todos conhecem a todos e a mensalidade sempre pode ser paga atrasada. Aprendi a ler e a escrever com 6 anos, lembro pouco desse período, mas guardei o nome e a fisionomia da minha primeira professora, Leila, tinha covinha na bochecha e era muito paciente. Quando li minha primeira frase, nasci pela segunda vez.

Dos meus muitos nascimentos, quase todos, a figura do docente estava lá auxiliando no parto. Fabiana, minha primeira professora de redação, me viu crescer e acabou sendo minha professora porque ela dava aula nesta escolinha de bairro que mencionei acima. Contei que conseguia digitar rápido no meu computador usado 386, presente da minha irmã mais velha que vivia no Nordeste e tinha uma situação financeira melhor que a nossa, mas que não tinha internet. Ela me pediu pra digitar um trabalho da graduação dela sobre Fernando Pessoa. E aí aconteceu a mágica. Fiquei fascinada com aquele português que tinha muitos heterônimos, que se multiplicava em vários, assim como a Horcrux (o bruxo insere em objetos partes de sua alma) nas histórias do Harry Potter. Fernando Pessoa faz isso com as palavras, transfere pedaços de sua alma em cada poema e eu em estado de encantamento fui presenteada por ela com o livro "A mensagem de Pessoa". Depois desse livro, nasci pela terceira.

Dos fingimentos de ser poeta, acho que aprendi a (res) significar as dores da infância muito bem. Filha de costureira e neta de dona de casa, nunca tive incentivo direto dentro de casa para ler e escrever, mas minha família vivenciava o universo musical, alguns cantavam e outros compunham. Um dos meus tios chegou a participar do quadro de calouros do Chacrinha. Minha mãe cantou por um período curto de tempo em barzinhos. Mas ninguém seguiu carreira musical, minha mãe continuou costurando e costura até hoje; um tio sobrevive como pintor em obras; um outro é pedreiro; o mais velho trabalha com dedetização e abriu uma pizzaria; e eu virei estudante de Letras. 
Mas como cheguei até aqui? Minha mãe cursou até a sétima série e meu pai até a quarta, ambos não possuem prática de leitura: nem jornal e nem livros. Eles só trabalhavam e sofriam, o gênero literário daqui de casa era o dramático. A vida de minha mãe sempre foi rodeada de problemas e a válvula de escape era ouvir música e reunir a família nos churrascos dos finais de semana em casa. Não tive uma cultura de leitura dentro de casa, muito menos dentro da escola. Mas o incentivo partiu dos professores. Eles foram figuras importantes e então tentei meu primeiro concurso: edital do Centro de Educação Federal Tecnológica (CEFET). Cursar o ensino médio em uma escola renomada e federal colocou tudo de cabeça para baixo. De certa forma, eu estava sendo privilegiada, ninguém da minha família cursou um ensino destes. Na escola, a escrita ia assumindo importância para mim, à medida que ia me politizando. Com quinze anos descobri o que era passeata, depois fui coordenadora de cultura do grêmio estudantil e promovi um evento com debates sobre Direitos Humanos e capoeira. Eu não sabia, mas já estava escondido em mim um lado produtora cultural que anos depois iria se revelar.

Em 2009, conheci a Apafunk e em 2010 me filiei ao PSOL. Como gremista estudantil me envolvi com movimentos Estudantis e partidários. A Apafunk, conheci por meio de Guilherme Pimentel, que na época era estudante de direito da Universidade Estadual do Rio de Janeiro (UERJ) e membro do movimento "Direito para Quem". Lembro quando Guilherme falou sobre maioridade penal numa atividade do grêmio estudantil do CEFET de Nova Iguaçu. Neste momento, conheci vários grupos e partidos de esquerda. Foi quando nasci pela quarta vez.

Em 2011, me afastei dos movimentos sociais e por problemas pessoais, parti para o Nordeste, onde vive minha irmã mais velha (logo depois do falecimento da minha avó - morri pela primeira vez). Vivi um ano em Aracaju, cidade pequena, a menor capital do Brasil e bem diferente cultural e socialmente da Baixada Fluminense. Foi neste período que a palavra "território" entrou no meu vocabulário. Eu precisei sair da minha cidade para me reconhecer como iguaçuana. Foi em Aracaju, que percebi que quando estava no Rio, morava na Baixada, mas vivia focada na capital, não olhava para o meu próprio lugar, habitava Nova Iguaçu de fora para dentro.

Fui bolsista do Programa Universidade para Todos (Prouni) em uma faculdade particular, por lá e cursei um ano de Letras mais como distração e terapia do que como paixão. Participei de um concurso de poesia (até aqui já estava escrevendo com frequência) e com o prêmio de primeiro lugar viajei para Salvador. Objetivo? Conhecer um sarau de poesia, recomendado por Mano Teko, que na época era presidente da Apafunk. Quando ouvi o poeta Nelson Maca vivendo, sentindo e 
incorporando a poesia, nasci pela quinta vez. Entendi que a escrita de "carne e osso" estava na rua.

Teko me contou da proposta de inserir intervenções poéticas nas rodas que a Apafunk estava promovendo por alguns espaços públicos da cidade do RJ. Daquela conversa, decidi voltar pra Nova Iguaçu, lugar que sempre vivi mas que jamais conheci. Nasci pela sexta vez e desta vez eu não era mais carioca e sim "baixadense".

O retorno foi difícil. Estávamos endividadas e ainda pagando empréstimo feito para bancar o caminhão de mudanças. Fui trabalhar como recepcionista num preparatório para concursos e ao descobrir que era um curral eleitoral, pedi demissão. O jogo virou quando finalmente, ingressei na UFRRJ - campus Nova Iguaçu. Não prestei vestibular para nenhuma outra Universidade. Queria estudar no meu território! Entrar numa universidade pública, me fez nascer pela sétima vez.

Começou a pesar no bolso e no psicológico eu ter que me deslocar de Nova Iguaçu até a Cinelândia tarde da noite e durante a semana para o Sarau Apafunk principal espaço de lazer e referência pra mim. Decidi, então, que faria algo parecido em algum espaço público da cidade de Nova Iguaçu. Surgiu assim o Sarau "V" de Viral. Primeiro sarau de rua, de ocupação e intervenção do espaço público na cidade de Nova Iguaçu. Com o surgimento do Sarau, me projetei, conheci outros espaços culturais já existentes na cidade e adjacências e nasci pela oitava vez. Passei a viver a minha cidade de dentro para fora.

Como disse Galeano, nós não somos feitos de átomos, como acreditam os cientistas, somos feitos de histórias. E como se conhecer e se reconhecer sem saber a nossa própria história? Se historicamente ela sempre foi contada pelo vencedor, pelo branco e europeu? Entendi a importância dos espaços nas periferias. O Sarau $V$ é um evento periférico onde podemos contar outras histórias. No Sarau V, me transformo em $\mathrm{MC}$ e o microfone numa arma de palavras. No Sarau V, o microfone é aberto e na rua: local onde as pessoas têm a oportunidade de expandir-se através do contar-se para o outro.

Desde 2013, o Sarau V acontece, mensalmente, na Via Light, no Centro de Nova Iguaçu. O Sarau dialoga com diversas linguagens artísticas, como o teatro, o circo, a poesia, o funk, o hip-hop, a pichação e o grafite. É uma ação coletiva protagonizada por jovens da Baixada Fluminense; uma intervenção que busca escrever e constituir novos imaginários sobre e para a Baixada Fluminense. O "V", como é conhecido, vem oxigenando a cena cultural da cidade de Nova Iguaçu, influenciando outros movimentos que surgiram com o mesmo recorte e ocupando o espaço público em outras cidades da Baixada, como o Sarau Rua, em Nilópolis e o Caldo de Cultura, em Mesquita. No "V" a Baixada não é unicamente o lugar de 
mazelas e de violência, o lugar do "corpo estendido no chão"; no "V" reescrevemos o nosso território por um olhar de dentro, um olhar que desvela toda a nossa criatividade e a nossa potência, como poetas, como escritores, como fazedores de cultura e contadores de nossas próprias histórias.

\section{TEORIZANDO SOBREVIVÊNCIAS E NASCIMENTOS}

As narrativas de Calazans e Janaína interligam espaços e tempos, encenando cronotopos, ou seja, condensações de índices de espaço e tempo - e suas concretizações em imagens de pessoa humana (BAKHTIN, 1981). O tempo dos nascimentos e das sobrevivências condensa e concretiza marcos espaciais que vão ganhando sentido no trânsito de Calazans e Janaína por vários territórios da cidade: estar 'dentro e fora' do Complexo do Alemão, estar 'dentro e fora' de Nova Iguaçu, estar 'dentro e fora' da escola. É, portanto, nesse trânsito, que esses sujeitos se fragmentam, se reinventam, sobrevivem e renascem em diversos contextos.

Nossa posição aqui é a de que as trajetórias de socialização na fala e na escrita narradas por Calazans e Janaína são um desafio às circunscrições comumente delineadas em discursos leigos e especializados sobre formas legítimas de escrever, falar e estar na escola. Como aponta Nilda Alves (2010), a escolarização não é algo que se dá apenas no espaço circunscrito da escola. Os sujeitos, segundo a autora, estão inseridos em "múltiplas redes educativas", circuitos de consorciação e conflito cujas tramas, nuances e interconexões tornam opacas as distinções entre (o que se aprende) "dentro" e "fora" escola. Daí Alves (2010, p.1197) falar em dentrofora: "precisamos compreender que vivemos todos dentrofora das escolas e que o que é aprendidoensinado nas tantas redes de conhecimentos e significações em que vivemos entra em todos os contextos, porque encarnado em nós" (itálicos da autora). Nos termos de Calazans, o Complexo do Alemão é a sua primeira escola, aquela que ele tem de "abandonar" para adentrar a escola legítima. No entanto, esse abandonar é apenas parcial porque o conhecimento adquirido em seu território de nascimento aliado àquele aprendido na igreja, no samba, no funk, no partido político e em outras redes - se recontextualiza na escola (legítima), ao mesmo tempo em que transborda suas arestas. Escrever no Complexo do Alemão, antes do Colégio Pedro II e da Fiocruz, está "encarnado" em Calazans; ler Harry Potter antecede e contamina a leitura que Janaína faz de Fernando Pessoa, na escola. Nesse circuito, a escola é um importante nó, mas não o único, de uma sinuosa trajetória de socialização.

Nas histórias de Janaína e Calazans, a escrita é constituída de diversas maneiras - da escrita e da leitura do funk, nos becos da favela, à escrita e leitura da gramática 
padrão, nos bancos escolares; da escrita da primeira professora, na escolinha de bairro, à reescrita do próprio território e da própria identidade, nas ruas da cidade. Janaína e Calazans parecem tecer narrativas em que as múltiplas redes educativas são acompanhadas por letramentos múltiplos (ROJO, 2009). Trata-se de formas situadas de uso da leitura e da escrita que, nos termos de alguns pesquisadores dos Novos Estudos de Letramentos (STREET, 2014; MAHIRI, 2008; BARTON \& UTA, 2010), situam-se tanto no interior de "letramentos marginais e/ou vernaculares", quanto no espaço daqueles concebidos como "letramentos escolares e/ou hegemônicos." Para a perspectiva dos Novos Estudos dos Letramentos, enquanto os letramentos hegemônicos são escolarizados, reconhecidos como a única forma legítima de escrita - um índice de inteligência e prestígio -, os letramentos vernaculares estão relacionados com escritas incipientes e ordinárias e, além disso, são formas de letramentos frequentemente ignoradas e tidas como irrelevantes pelas instituições dominantes, principalmente pela escola (STREET, 2014).

No entanto, entendemos que circunscrever a forma pela qual Janaína e Calazans narram a escrita e a leitura em uma dessas duas tipologias não dá conta de toda a complexidade de significados que essa prática assume em suas trajetórias. Como já destacamos, é no trânsito por espaços físicos e/ou simbólicos que Janaína e Calazans apropriam-se de letramentos hegemônicos e vernaculares. A apropriação da escrita em suas trajetórias se dá não apenas em territórios em que os letramentos hegemônicos costumam ganhar valor e validade - o Colégio Pedro II, a Escola Politécnica de Saúde Joaquim Venâncio/Fiocruz, a UFRRJ, a UFRJ -, mas também nos espaços de produção do funk, nos saraus nas periferias, no canto gospel das igrejas evangélicas.

Aproveitaremos uma inferência metapragmática de Janaína para argumentar que entender esses letramentos demanda que adotemos táticas que os posicionem não como letramentos hegemônicos ou vernaculares, mas sim como transletramentos. Janaína batiza de "V" de viral o sarau por ela inaugurado no espaço público de Nova Iguaçu. Escritas e falas virais são aquelas que se disseminam: repetem discursos prévios e os deslocam ao mesmo tempo (DERRIDA, 1977; BUTLER, 1997), infectam suas/seus usuárias/os com formas particulares de mapear o campo social (CALDEIRA, 2003) e as/os interpelam a ocupar certas posições na vida social (BRIGGS, 2005). Diz Janaína que o surgimento do Sarau "V" a "projetou": formas em trânsito, os versos ali produzidos permitiram que ela "conhec[esse] outros espaços culturais já existentes na cidade e adjacências e nasc[esse] pela oitava vez. Passei a viver a minha cidade de dentro para fora." Transletramentos são, assim, formas virais: replicam instâncias prévias de contaminação com a escrita e as disseminam. Nessas 
trajetórias de replicação, os transletramentos podem reconfigurar circunscrições cronotópicas: com o sarau, Janaína passa a viver Nova Iguaçu "de dentro para fora." (Vale lembrar que, nas narrativas de Calazans e Janaína, "dentro" e "fora", além de não-dicotômicas, são formas estratégicas de se posicionar no tempo e no espaço, sujeitas a contínua revisão).

Esse transitar não é destituído de conflitos; ao contrário, é permeado por "muros", como enfatiza Calazans. Ou seja, transletramentos são tecidos em movimentos atravessados por embates e relações de poder - o que contará como escrita, o que contará como padrão culto e o que contará como saber serão sempre disputados localmente. Brian Street e Inês Signorini teorizam, de diferentes modos, a produção desses muros. Do trabalho de Brian Street (e.g. STREET, 2014) inferimos que instâncias de poder enunciam discursos que produzem uma pedagogização do letramento. Ou seja, tradicionalmente, nas escolas, funda-se a falsa dicotomia oral/escrito, e os processos sociais de leitura e escrita são narrados por uma voz pedagógica como se fossem competências independentes, neutras e não carregadas de significação para as relações de poder e ideologia. $\mathrm{O}$ autor aponta ainda que, nesse processo, a língua é tratada como um código formal, fixo, descorporificado e exterior aos sujeitos que falam e escrevem. Do trabalho de Inês Signorini (e.g. SIGNORINI, 2004) lemos que tem havido, em discursos acadêmicos e escolares no Brasil, uma espécie de polarização diglóssica entre modalidades e variedades de uso da língua: por exemplo, é relativamente unânime nos círculos de formações de professores que aprendizes, em especial aqueles de camadas periféricas das sociedades, devem aprender a produzir e ler textos "adequados" a diversas situações de uso da língua. No entanto, essa noção de adequação é normalmente guiada por uma lógica diglóssica - i.e., a "contraposição entre língua oral e língua escrita como dois pólos que se excluem" (p.96). Operando em circuitos oficiais, a mentalidade diglóssica é moderna por natureza; suas divisões circunscritas, entre oral e escrito, padrão e não-padrão, desconsideram "o campo das interseções entre práticas orais e práticas escritas como uma zona de fronteira e ao mesmo tempo de interface, onde operam os processos de transformação do sujeito aprendiz e de sua língua" (p.95-96).

A pedagogização do letramento e a mentalidade diglóssica são produtoras de muros - circunscrições e fronteiras reconhecidas por Calazans e Janaína. Produzidos no campo escolar com as nuances acima apontadas por Street e Signorini, esses muros, na complexa realidade vivida por Calazans e Janaína, coincidem também com aqueles erigidos na "cidade partida" - alusão indireta de Calazans à obra de Zuenir Ventura (1994), que inaugura no discurso midiático a dita cisão entre 
"asfalto" e "morro". Esses dois jovens, no entanto, recusam-se a ser modernos: em vez de confinarem-se aos regulamentos das mônadas contemporâneas, eles preferem hibridar-se nas interseções e zonas de fronteira apontadas por Signorini (2004). Assim, ao mesmo tempo em que reconhecem muros, Calazans e Janaína esforçam-se por desconstruí-los: para Janaína, "[n] o "V" a Baixada não é unicamente o lugar de mazelas e de violência, o lugar do "corpo estendido no chão"; no "V" reescrevemos o nosso território por um olhar (...) que desvela toda a nossa criatividade e a nossa potência"; para Calazans, o espaço-tempo escolar tem sido estratégico para "pular os muros, mas nunca esquecer o meu verdadeiro lado, até a completa derrubada desses muros."

Localmente, escrita e leitura encenam transletramentos não apenas por replicar experiências passadas de socialização com formas hegemônicas e vernaculares de letramentos, mas também porque invocam aspirações e engajamentos políticos. Não é por acaso que a própria escolarização desses dois jovens é permeada por suas participações em grêmios estudantis e movimentos sociais.

Diante da complexidade de trânsitos, instituições e imagens de pessoa humana invocados nas narrativas desses jovens, cabe aqui nos perguntarmos pela localização da escola nessas histórias de vida. Angela Kleiman (1995), uma das principais pesquisadoras dos estudos dos letramentos no Brasil, afirma que escola é a mais importante agência de letramento da sociedade moderna. Dito de outro modo, seria principalmente na escola que os sujeitos se engajariam em atividades de leitura e escrita em vistas de um objetivo comum. No entanto, acreditamos que deveríamos nos perguntar: principal agência de que tipo de letramento? Ao assumirmos que a escrita não é tecida apenas no interior da escola, mas também num circuito muito mais amplo, adquirindo diversos significados e usos locais de acordo com as demandas, os recursos e as histórias pessoais, julgamos que seria difícil circunscrever em um único contexto a agência de letramento mais determinante não só na vida de Janaína e Calazans, mas também na de qualquer outra pessoa. Desse modo, compreendemos que a escola funciona menos como um local limitável onde se aprende a ler e escrever e mais como a instituição que decreta performativamente o que conta como escrita em nossa sociedade, quais a dimensões dessa prática e, ainda, qual é a forma do corpo do sujeito que escreve. Nos termos da visada teórica de Pinto (2013), a escola, ao circunscrever a língua e a escrita em mônadas aparentemente desconectadas de trajetórias de vida, prefigura identitariamente quem pode escrever e como se deve escrever - via de regra, de acordo com prefigurações brancas, masculinas e heteronormativas de pessoa humana. No entanto, ao considerarmos os fluxos de Janaína e de Calazans e suas 
trajetórias de socialização na escrita (i.e., seus transletramentos), vemos também que performativos prefigurados estão sempre sob constante ameaça. Dito de outro modo, injunções prefiguradas nem sempre se sustentam nas trajetórias de socialização na escrita de sujeitos, tampouco em seus cotidianos escolares.

No trabalho de Ana Lúcia de Souza (2011) na periferia de São Paulo, lemos que não é a escola, mas sim o hip hop que funciona como um poderoso agente de letramento, produzindo leituras e escritas contra-hegemônicas, que escancaram a prefiguração identitária que está na base da invenção da língua portuguesa (MOITA LOPES, 2013) e, consequentemente, da escrita escolarizada. Segundo Souza (2011, p.40), "para ser leitor, dentro de um processo em que a palavra escrita é europeia e responde às teorias racistas vigentes, é preciso embranquecer". Assim, em um jogo de disputas e reexistências, o hip hop contamina a escrita escolarizada com outros corpos e outras vozes, transformando continuamente aquilo que conta como língua e como escrita nos regimes de letramentos hegemônicos.

Nesse sentido, observamos que na história de vida de Janaína e de Calazans, o funk, o samba, o hip-hop, o grafite, a pichação, a rua são "agentes de letramento" tão poderosos quanto a professora de redação das escolinhas de bairro e os docentes de outras instituições escolares que cruzam os seus caminhos. Nesse transitar entre letramentos, a língua deixa de ser um código formal e exterior, transformandose numa forma de ação no mundo, uma prática fundamentalmente dialógica de engajamento com o outro. Parafraseando MC Janaína, nas ruas, a palavra vira arma, pois se expande e se democratiza.

\section{TRANSLETRAMENTOS E SOBREVIVÊNCIA}

Inspiradas/os pela crítica do filósofo Jacques Derrida $(1971,1979)$ às visões etnocêntricas de escritura, gostaríamos ainda de defender que transletramentos são também formas de sobrevivência. A ordem indexical (SILVESTEIN, 2003) invocada por Calazans e Janaína - i.e. a correlação não unificada, nos fatos sociolinguísticos, entre elementos microssociais (ou índices, na terminologia peirceana) e processos macrossociais (ou objetos, na mesma terminologia) - é, necessariamente, uma ordem política. Nas periferias do Rio de Janeiro e de outras cidades brasileiras, os espaços subalternizados aos quais dedicamos boa parte de nossa reflexão como linguistas aplicadas, sociolinguistas, linguistas de texto, analistas de discurso ou antropólogas são muitas vezes criminalizados e submetidos ao lado penal do Estado democrático de direito. Perceba-se que na narrativa de Calazans, as Unidades de Polícia Pacificadora e a violência de Estado ocupam um lugar central. 
Como aludimos acima, juntamente com Calazans, em 2015, procedemos a uma empreitada teórica de estudar a questão da sobrevivência - algo que havia emergido do campo, numa entrevista com o próprio Calazans, em 2012, quando ele correlacionou a cultura na favela a uma cultura de sobrevivência, i.e., uma forma coletiva de imaginar a partilha de recursos simbólicos e materiais em territórios periféricos (FACINA, 2014). Inspiradas/os pela ideia de sobrevivência, encontramos autoras e autores que criticam a ideologia vitalista da filosofia ocidental $(\mathrm{CHEAH}$, 2003), formulada com base em dicotomias como vida/morte; ou em algum tipo de presença imanente, em que algumas vidas valem mais do que outras (LEVI, 1988, BUTLER, 2005); ou ainda na atribuição desigual de voz e verdade às narrativas, atribuindo citacionalidade a algumas e silenciamento a outras (BURGOS, 1993, ARIAS, 2001, BRIGGS, 2007). Para nós, sobreviver, além de implicar movimento, é uma forma de criticar binarismos como viver e morrer. Derrida (1979, p.89) argumenta que a sobrevivência está para além da dicotomia moderna viver/morrer: "o sobreviver transborda, ao mesmo tempo, o viver e o morrer, suplementando-os, um e outro, como um sobressalto e um alívio temporário, parando a vida e a morte e ao mesmo tempo".

A demanda de narrativas apresentada por Adriana Lopes aos dois jovens, assim, produz respostas sobre os letramentos que não apenas sobrevivem à demanda em si (no sentido trivial de sucedê-la), mas também entextualizam - isto é, recontextualizam e invocam elementos de uma história de uso (BAUMAN \& BRIGGS, 1990) - uma cadeia de interlocuções. Retomemos um excerto da narrativa de Calazans:

Vivendo entre o perigo dramático da violência no dia-a-dia das operações policiais e a correria cotidiana para inventar a sobrevivência, comecei a ler o mundo que estava ao meu redor. Se por um lado, a pobreza, a ausência de serviços públicos, a falta de saneamento básico colocavam-se como prisões que não nos permitiam sair "desse lugar"; por outro lado, foi a partir dessa escassez que aprendi e comecei a me alfabetizar.

O evento de letramento onde se produziu o excerto acima transborda a si próprio. A perspectiva sobre viver e morrer na favela produzida por Calazans tem uma temporalidade aberta - aponta para o passado e futuro e para diversas camadas da vida social. Assim, esse evento requer uma "análise de discurso para além do evento de fala", como sugerem Wortham \& Reyes (2015) no título de sua obra recente. Nos termos de nossa etnografia, essa temporalidade aberta dos letramentos tem implicado não apenas traçar circuitos inteligíveis às nossas aspirações e aos constrangimentos das tramas institucionais de que participamos, mas também enfrentar demandas dos próprios sujeitos no campo. Por exemplo, 
como se lê no excerto acima, para nós, entender regimes de letramento também tem implicado entender regimes de policiamento. No metadiscurso de Calazans, alfabetizar-se emerge não da vocação iluminista dos agregados modernos, mas da resposta à violência policial e à "ausência de serviços públicos" (que não sejam UPPs ou presídios).

Escrever, para Janaína e Calazans, coaduna-se com os títulos de suas narrativas: 'Nascimentos' ou 'Sobrevivências'. Obviamente, ela e ele não estão se referindo a um sentido biológico de nascer ou sobreviver, mas ao seu sentido político. Trata-se de um nascimento ou de uma sobrevivência que "vem depois", ou melhor, do surgimento de uma segunda natureza, que não inaugura o puro e genuíno; ao contrário, traduz ou reescreve a vida a partir de uma inserção política no mundo.

É nessa repetição e nessa reinscrição que residem o que estamos chamando de sobrevivência. Já que todo texto carrega a história de seu uso consigo, o signo 'favela', ao ser enunciado por Calazans, carrega as marcas de um discurso que situa esse território unicamente como "o outro lado da cidade da cidade partida" - local da pobreza, da miséria e do crime. Porém, ele inverte essa perspectiva, entextualizando outros discursos, aqueles que entendem a favela não como o espaço da alteridade assustadora e irredutível, mas como o território de origem e de habitação; o território do cotidiano e, como tal, o local onde se cria, se sobrevive e se aprende: "onde se escreve, mesmo sem saber escrever."

Como já apontamos, em contextos de sobrevivência, viver e morrer não se opõem. Trata-se antes de forças agentivas que moldam e dimensionam a experiência. Ao fim de sua narrativa, Calazans relata que um de seus grandes amigos foi morto na invasão empreendida pelo exército em 2010, etapa inicial para a implantação das Unidades de Polícia Pacificadora no Complexo do Alemão. Uma vez que, em vista do escasso letramento escolar do amigo, Calazans havia ignorado sua demanda para lhe emprestar um "daqueles livros de política que [ele] sempre lia", o pesar e a tristeza pela morte ulterior do rapaz o fazem inscrever a memória do amigo como dedicatória à sua monografia sobre funk e favela. Reinventando a vida "a partir daquilo que nega a própria vida" - a morte? -, Calazans então questiona o preço que se paga pela hierarquização topográfica entre o "dentro" e o "fora" do território. Tal como Corisco em Deus e o Diabo na Terra do Sol (ROCHA, 1965), que morre junto com Virgulino Lampião e, por isso, "precisava ficar de pé, lutando sem fim, desarrumando o arrumado, até que o sertão vire mar e o mar vire sertão", o amigo de Calazans (e o próprio Calazans) desafiam a morte, fazendo a escrita 
sobrevivente de seu amigo transletrar-se e sobreviver em sua monografia - e de lá para outros artefatos, como o que você tem diante de seus olhos agora.

De maneira semelhante, Janaína se apropria da escrita em diversos momentos de seus nascimentos e mortes em vida. E a escrita vai ganhando um significado fundamental "à medida que [ela vai se] politizando." Assim, sua trajetória de socialização na escrita culmina com a ressignificação de si mesma e de seu próprio território. Em suas próprias palavras: "de dentro para fora". Nesse trânsito, a Baixada também é ressignificada: ela deixa de ser o lugar da "violência" e das "mazelas" e passa a ser entextualizada como o território "da criatividade", da "potência juvenil" e da "poesia de carne e osso" que se escreve nas ruas.

\section{PALAVRAS FINAIS}

Essas narrativas podem ser lidas como metáforas para outras histórias: de "outros moleques, negros e pobres que (...) nasceram juntos com o surgimento do símbolo favela", como relata Calazans, ou de outros jovens que participam de intervenções culturais em territórios periféricos, conforme a iniciativa de Janaína. A projeção escalar (CARR \& LEMPERT, 2016) que fazemos aqui não coincide com as projeções comumente feitas sobre a juventude periférica na mídia corporativa, na política e até mesmo na escola - nelas, esses sujeitos são dimensionados como destituídos de habilidades e competências, marcados pelo "iletramento" ou pela afasia; seres que necessitam ser colonizados, civilizados e educados.

Aqui, as performances narrativas de Calazans e Janaína encenam alguns traços do que essa juventude efetivamente faz em termos de cultura, de educação e de letramentos. Numa visada etnográfica, nossa aspiração foi indagar não propriamente o modo "como o letramento hegemônico transforma os sujeitos", mas sim "como os sujeitos transformam os letramentos hegemônicos". Em outras palavras, procuramos trazer à tona a forma pela qual esses sujeitos produzem transletramentos, i.e., práticas de replicação e deslocamento de experiências de socialização na escrita marcadas pelo cruzamento de letramentos escolarizados e vernaculares. Escrever, nesse sentido, é traduzir - transformar enunciados prévios, ao mesmo tempo em que se assume autor/a desses enunciados.

Entendemos que produzir novas imagens de tempo, espaço e pessoa humana no campo de estudos da linguagem e dos letramentos é um passo fundamental para a construção de pedagogias mais sensíveis às formas pelas quais as/os estudantes mobilizam recursos simbólicos e materiais específicos no interior de suas comunidades. Além disso, produzir novas dimensões em discursos especializados 
pode contribuir para a construção de novas visibilidades, para que os sujeitos possam encontrar na escola formas de diálogo - "pontes e não muros" - entre os diversos significados e usos da leitura e da escrita, bem como modos de empoderamento para suas identidades e letramentos em contínua mutação.

\section{REFERÊNCIAS BIBLIOGRÁFICAS}

ALVES, Nilda. (2010). A compreensão de políticas nas pesquisas com os cotidianos: para além dos processos de regulação. Educação \& Sociedade v.31, n.113, pp. 1195-1212.

ANZALDÚA, Gloria. (2000). Falando em línguas: uma carta para mulheres escritoras do terceiro mundo. Revista de Estudos Feministas. v. 8, n. 1, pp. 229-236.

ARIAS, Arturo. org. (2001). The Rigoberta Menchu controversy. Minneapolis: University of Minnesota Press.

BARTON, D. and UTA, P. (2010). The antbropology of writing. Understanding textualy-mediated worlds. London, Continuum.

BAKHTIN, Mikhail. (1981). Forms of Time and of the Chronotope in the Novel. In: Holquist, Michael (org.) The Dialogic Imagination, Four Essays by M. M. Bakbtin. Austin: University of Texas Press, pp.84-258.

BAUMAN, R.; BRIGGS, C. (1990). Poetics and performance as critical perspectives on language and social life. Anmual Review of Antbropology, v. 19, pp. 59-88.

BAUMAN, R.; BRIGGS, C. (2003). Voices of modernity: Language ideologies and the politics of inequality. Cambridge: Cambridge University Press.

BEHAR, Ruth; GORDON, Deborah. orgs. (1995). Woman Writing Culture. Berkeley: University of California Press.

BLOMMAERT. (2010). The Sociolinguistics of Globalization. Cambridge: Cambridge University Press, 2010.

BLOMMAERT, J. (2008). Grassroots literacies: Writing, identity and voice in Central Africa. London: Routledge.

BORBA, Rodrigo. (2016). O (des)aprendizado de si: transexualidades, interação e cuidado de si. Rio de Janeiro: Editora Fiocruz.

BRIGGS, Charles. (2005). Communicability, Racial Discourse, and Disease. Annual Review of Antbropology, v. 34, pp. 269-291. 
BRIGGS, Charles. (2007). Anthropology, Interviewing, and Communicability in Contemporary Society. Current Anthropology, vol. 48, n. 4, 2007c, pp. 551-580.

BURGOS, Elizabeth. (1993). Meu nome é Rigoberta Menchú e assim nasceu minba consciência. Rio de Janeiro: Paz e Terra.

BUTLER, Judith. (1997). Excitable Speech: a Politics of the Performative. Londres e Nova York: Routledge.

BUTLER, Judith. (2005). Frames of war: When is life grievable? London: Verso Books.

CALDEIRA, Teresa. (2003). Cidade de muros: crime, segregação e cidadania em São Paulo. Trad. Frank de Oliveira e Henrique Monteiro. 2.ed. São Paulo: Edusp/Editora 34.

CARR, E.; LEMPERT, M., orgs. (2016). Scale: Discourse and Dimensions of Social Life. Berkeley: University of California Press.

CASTILHO, Ataliba \& Dino Pretti, orgs. (1987). A linguagem falada culta na cidade de S. Paulo: materiais para seu estudo. São Paulo: T. A. Queiroz/Fapesp, v. II.

CHEAH, Peng. (2003). Spectral Nationality: Passages of Freedom from Kant to Postcolonial Literatures of Liberation. Nova York: Columbia University Press, 2003.

CHEAH, Peng. (1999). Spectral Nationality: The Living On [sur-vie] of the Postcolonial Nation in Neocolonial Globalization. Boundary 2, v. 26, n. 3, pp. 225-252.

CLIFFORD, J. (1986). "On Ethnography Allegory." In: Clifford, J.; Marcus, G. Writing Culture. The Poetics and Politics of Etnography. Los Angeles: University of California Press.

DERRIDA, Jacques. (1971). A escritura e a diferença. São Paulo: Perspectiva.

DERRIDA, Jacques. (1977). Signature Event Context. Trad. Samuel Weber e Jeffrey Mehlam. Glyph, v. 1, pp. 172-197.

DERRIDA, Jacques. (1979). Living on/Border Lines. Trad. James Hulbert. In: Bloom et al. (orgs.) Deconstruction and criticism. London: Continuum, pp. 62-142

FACINA, A. (2014). Sobreviver e sonhar: reflexões sobre cultura e "pacificação" no Complexo do Alemão. In: Pedrinha, R. D.; Fernandes, M. A. (orgs.). Escritos transdisciplinares de criminologia, direito e processo penal: bomenagem aos mestres Vera Malaguti e Nilo Batista. Rio de Janeiro: Revan, pp. 39-48. 
GARCEZ, Pedro. (2017). Conceitos de letramentos e a formação de professores de línguas. Texto inédito preparado para o II Seminário Letramento e Transdisciplinaridade, IEL/Unicamp, 29 e 30 de agosto de 2017.

IRVINE, Judith; GAL, Susan. (2000). Language ideology and linguistic differentiation. In: Kroskrity, Paul V., ed. Regimes of language: Ideologies, polities, and identities. James Currey Publishers, 2000, pp.35-84.

JACQUEMET, Marco. (2016). Transidioma. Revista da Anpoll v.1, n.40, pp. 19-32.

KLEIMAN, Angela B., Org. (1995). Os significados do letramento: uma nova perspectiva sobre a prática social da escrita. Campinas: Mercado das Letras.

KROSKRITY, Paul V., org. (2000). Regimes of language: Ideologies, polities, and identities. James Currey Publishers.

LATOUR, Bruno. (1994). Jamais fomos modernos: ensaios de antropologia simétrica. São Paulo: Ed. 34.

LEVI, Primo. (1988). É isto um bomem? Rio de Janeiro: Rocco.

LOPES, Adriana. (2011). Funk-se quem quiser no batidão negro da cidade carioca. Rio de Janeiro: Bom Texto.

LOPES, Adriana, SILVA, Daniel \& FACINA, Adriana. (2014). Letramentos de ruptura: as escritas do funk carioca. Anais do V Colóquio Letramento e Cultura Escrita. Belo Horizonte: CEALE/UFMG, v. 1. p.1-9

MAHIRI, J. (2008) What they don't learn in school. Literacy in the lives of urban youth. Whashington: Peter Lang.

MAIA, Junot. (2017). Fogos digitais: Letramentos de sobrevivência no Complexo do Alemão/RJ. Tese de doutorado em Linguística Aplicada, Campinas, IEL/Unicamp.

MOITA LOPES, L. P., org. (2013). Português no século XXI: Cenário geopolítico e sociolinguístico São Paulo: Parábola.

MORAGA, Cherríe \& ANZALDÚA, Gloria. (Orgs.). This bridge called my back: writings by radical women of color. New York: Kitchen Table.

PINTO, Joana Plaza. (2013). Prefigurações identitárias e hierarquias linguísticas na invenção do português. In: Moita Lopes, L. P. (org.) Português no século XXI: ideologias linguísticas. São Paulo: Parábola Editorial, pp. 120-143. 
ROCHA, Glauber. (1965). Deus e o Diabo na Terra do Sol. Vol. 1. São Paulo: Editora Civilização Brasileira.

ROJO, Roxane. (2009). Letramentos múltiplos, escola e inclusão social. São Paulo: Parábola.

SIGNORINI, Inês. (2002). Por uma teoria da desregulamentação lingüística. In: Bagno, Marcos (org.). A linguística da norma. São Paulo: Edições Loyola, pp. 93-125.

SIGNORINI, Inês. (2004). Invertendo a lógica do projeto escolar de esclarecer o ignorante em matéria de língua. Scripta v.7, n. 14, pp. 90-99.

SILVERSTEIN, M; URBAN, G. (1996). Natural bistories of discourse. Chicago: University of Chicago Press.

SILVERSTEIN, Michael. (1979). Language structure and linguistic ideology. In: Clyne, P.; Hanks, W. \& Hofbauer, C. (orgs.) The elements: a parasession on linguistic units and levels. Chicago: Chicago Linguistic Society, pp.193-247.

SILVERSTEIN, Michael. (2003). Indexical Order and the Dialectics of the Sociolinguistic Life. Language and Communication, v. 23, pp. 193-229.

SOUZA, Ana Lúcia Silva. (2011). Letramentos de reexistência: poesia, grafite, música, dança: bip-bop. São Paulo: Parábola.

STREET, Brian. (2009). Ethnography of writing and reading. In: Olson, D. R. \& Torrance, N. (orgs.) The Cambridge bandbook of literacy. Cambridge: Cambridge University Press, pp.329-345.

STREET, Brian. (2014). Letramentos sociais. São Paulo: Parábola.

THOMAS, Sue et al. (2007). Transliteracy: Crossing divides. First Monday. Disponível em: <http://journals.uic.edu/ojs/index.php/fm/article/view/2060/1908>. Último acesso: 30 out. 2017 .

VENTURA, Zuenir. (1994). Cidade Partida. São Paulo: Cia. das Letras.

WOOLF, Virginia. (2014 [1928]). Uma quarto só para si. Trad. Bia Nunes de Souza. São Paulo: Tordesilhas.

WORTHAM, Stanton; REYES, Angela. (2015). Discourse Analysis Beyond the Speech Event. Londres: Routledge.

Recebido: 02/09/2017

Aceito: 02/11/2017 